\title{
Gender and emotion in exile: Evelyn Scott and Cyril Kay-Scott's experience in Brazil (1914-1918)
}

\author{
Maria das Graças Salgado ${ }^{1}$
}

Resumo: Historicamente o exílio tem representado parte significativa da vida de escritores, artistas e intelectuais em toda parte. No Brasil, esse movimento migratório ocorreu sobretudo no período das duas grandes guerras. Foi o caso, por exemplo, da escritora americana Evelyn Scott que, no final de 1913, fugiu com Cyril Kay-Scott, um renomado médico e pesquisador, à época, casado, pai de quatro filhos e com mais que o dobro de sua idade. Sem passaportes, levando pouquíssimo dinheiro no bolso, o casal fugiu primeiro para Nova York, em seguida para Londres e finalmente para o Brasil, onde enfrentaram pobreza, fome e isolamento profundo. A experiência foi particularmente dolorosa para Evelyn Scott, que chegara ao Brasil grávida e teve que enfrentar um parto difícil na cidade de Natal (RN). O objetivo deste trabalho é investigar o discurso autobiográfico de Evelyn Scott e Cyril Kay-Scott sobre o longo exílio auto-imposto que viveram no Brasil entre os anos 1914 e 1919. A análise se baseia nas autobiografias Escapade, de Evelyn Scott, e Life is too short, de Cyril Kay-Scott. Evidências indicam que gênero e emoção são aspectos importantes que revelam diferenças não apenas de estilo como também de visões de mundo.

Palavras-Chave: Evelyn Scott; Cyril Kay-Scott; discurso; gênero; emoção; exílio.

\begin{abstract}
Historically exile has been depicted as a significant part of writers', artists', and intellectuals' life everywhere. In Brazil, this migratory move occurred mostly within the interwar period. That was the case, for instance, of the American writer Evelyn Scott who, in late 1913, eloped with Cyril Kay-Scott, a well-known medical doctor and researcher then married, father of four, and more than twice her senior. Without passports, taking with them very little money, the couple fled first to New York, then to London, finally to Brazil, where they eventually faced poverty, starvation and almost complete isolation. The experience proved to be particularly painful for Evelyn Scott, who was pregnant at their arrival and went through a difficult childbirth in the northeastern city of Natal. This work aims to examine Evelyn Scott and Cyril Kay-Scott's autobiographical discourse about their long Brazilian selfimposed exile, from 1914 to 1919. The analysis is drawn from the autobiographies Escapade, by Evelyn Scott, and Life is too short, by Cyril Kay-Scott. Evidences indicate that gender and emotion are important aspects that reveal differences not only in style but also in their worldviews.
\end{abstract}

Keywords: Evelyn Scott; discourse; gender; emotion; exile.

1 Doutora em Letras, professora Associada de Inglês no Departamento de Letras e Comunicação da Universidade Federal Rural do Rio de Janeiro. Membro do projeto de pesquisa "Gênero, Memória e Emoção no Discurso Autobiográfico em Inglês e Português" (UFRRJ). 


\section{Introduction}

The American writer Evelyn Scott was born Elsie Dunn (1893-1963) in the small city of Clarksville, Tennessee. She was the only child of Seely and Maude Thomas Dunn, two exemplars of a typical Southern aristocratic family who owned a tobacco plantation. Cyril Kay-Scott was born Frederick Creighton Wellman (1874-1960) in Independence, Missouri. He did not have the same aristocratic background as Evelyn Scott, but he also belonged to a prosperous family whose members were in the railroad business.

From the very beginning, the Scotts' story was affected by discrepancies that would count against them for the rest of their lives, notably Evelyn's age and Cyril's marital status. When they first met, Cyril was not only married, father of four and more than twice her senior, but he was also a well known medical doctor, researcher, and Dean of the School of Tropical Medicine at Tulane University, one of the most prestigious educational institutions (CALLARD, 1985, p.1-2). It was against this conflicting background that they fell in love and, in 1913, eloped from the United States in search of a completely unknown future in Brazil. In different periods of their lives, both of them wrote powerful autobiographical accounts of their tropical adventure. Evelyn wrote the first draft of her autobiography in loco. Cyrill wrote his twenty years later.

Scholars and biographers (BACH, 1989; JONES, 2001; WHITE, 1998; CALLARD, 1985; WELKER, 1958; SCURA, 1995) have pointed out that Evelyn Scott and Cyrill Kay-Scott's romance began and developed under a complex emotional context in which feelings of hatred, persecution, and revenge emerged from two main sources: Cyril's exwife, who refused to be replaced by a younger woman while losing her marital status, and Evelyn's parents, who refused to loose their only child from a social scandal that would become a police case.

The scandal became so out of proportion that the couple decided to adopt false identities in order to ran away from their hometown. Their itinerary included first a one-night stay in New York, then London. Once in London, for fear of being found by the police authorities and because they did not have any prospects of securing jobs there, Brazil became a possibility, the country where Cyril believed he could get a proper job.

The affair could have been considered just a major social scandal. However, it had also the ingredients to become a police case since it involved an older married man travelling with a minor. At the time this was ilegal and could have resulted in the imprisonment of Cyril Kay-Scott.

Considering the relevance of gender and emotion in autobiographical accounts in which the protagonist are a woman and a man reporting the same experience, this work aims to investigate Evelyn Scott's and Cyrill Kay-Scott's discourses about their selfimposed exile in Brazil. Having left behind their Southern upper-class background, and yet carrying with them these very same aristocratic values, how did they responde to the hardships of 'real life' in early twentieth century Brazil? How did gender and emotion shape their discourse about such extreme adventure?

The article is organized in the following order: In section 1, some relevant concepts are presented in order to show the importance of critical views of discourse, gender, emotion, and exile for the analysis proposed. Section 2 constextualizes the method describing the selection of the material and the criteria used for this sellection. In section 3, the analysis 
is developed exploring examples of exterts taken from the two autobiographical accounts in focus. Finally, conclusions are drawn, pointing out the importance of further research on the role of gender and emotion in exile experiences that involve couples in isolation.

I would like to thank the historians Oliver Marshall (King's College London) and Eduardo Silva (Fundação Casa de Rui Barbosa, Rio de Janeiro) for their generous support and critical reading of the manuscript.

\section{Relevant concepts:}

\section{Discourse}

One of the most prominent representatives of the approach of discourse as social practice embedded within power relations is Foucault (1972), to whom the term discourse should be thought as social practices that form the objects of which they speak. Also concerned with power relations and the way they influence the production of text, Fairclough (1992) considers discourse a form of social practice as opposed to an individual activity, or as a mere reflex of situational variables. Complementing this social view of discourse but closely connected cognitive approaches, Van Dijk (1990) argues that, since individuals need a mental representation of power, the relationship between language and society is intermediated by cognitive structures. For the author, it is the construction of cognitive structures that establishes the relationship between society and power, not the objective reality in itself (VAN DIJK, 1990, p.164). Discourse meaning should thus include not only verbal and non-verbal observable elements, social interactions, and speech acts, but also cognitive representation and strategies involved during interpretation and production.

In this paper, the term discourse is used to refer to social practices in which power, culture and ideology influence the way people use language to act upon each other in specific social contexts.

\section{Gender}

In the 1970's the perception of language marked by gender gave rise to a wide range of perspectives that tried to account for the role of gender in discourse. The so-called differences'approach (LAKOFF, 1975) emerged as a landmark of analysis attempting to characterize existing differences between women's and men's language. Later on, the linguistic determinist approach suggested a historical male domination through language, understanding that language would have been planned by men to oppress women (SPENDER, 1980). As expected, alternative views to such approaches emerged. The first reaction came out through what was refered to as integrational approach (CAMERON, 1985). This perspective introduces a "discourse turn" in language and gender studies, emphasizing the historical, dynamic and interactive nature of language in use, an approach which requires that "any instance of language or linguistic units be considered in relation to the function they serve in particular situated uses, and [...] that the units themselves not be taken as fixed and immutable" (ECKERT \& McCONNEL-GINET, 2003). Gender studies then should not concentrate on the correlations between linguistic units and social categories of speakers but rather on analysis of the gendered dimension of ongoing discourse. According to this approach, language should not be separated from other forms of 
social behavior or from its social context. And linguistic theory should consider questions related to the meaning of language, to the definition of women's and men's language, to the connection between language and reality, and to the relationship between language and social minorities (CAMERON, 1985, p. 47).

Simultaneously to the appearance of the discursive view of language, there was a shift in gender studies, which promoted the idea of gender not as an identity that people simply "have" but as a phenomenon that involves what people "do". Gender therefore should not be taken for granted as something that

[...] just exist, but as something that is constantly produced, reproduced, and changed through people's performance of gendered acts, as they project their own claimed gendered identities, ratify or challenge other's identities, and in various ways support or challenge systems of gender relations (ECKERT \& McCONNEL-GINET, 2003, p.18).

The "performance turn" is today mostly associated with the influential philosophical approach (BUTLER, 1990), however, as early as the 1970's, different traditions of sociology and anthropology (GOFFMAN, 1979; KESSLER and McKERMMA, 1978) had already pointed out the signifancy of gender performance.

This article supports the idea of gender as historically situated discourse, and also an act that people perform acording to the context in which they occur. Bringing both the discursive and the performance turns together contributes to the notion of language and gender as essencially embedded in social practices that involve not just individuals and their individual choices and actions, but also ideological constraints that may shape these individual actions. In that perspective, "gender is not something given, but an achievement. Not cause, but effect” (ECKERT \& McCONNEL-GINET, 2003, p.18)

\section{Emotion}

Outside linguistics, studies have suggested that gender can be viewed as a sociocultural construct that shapes women and men's communicative behavior. According to this perspective, significant part of people's behavior is played by emotion, a category naturally associated with the definition of gender. Therefore, any discourse about emotion is also a discourse about gender (ABU-LUGHOD \& LUTZ, 1990). In the same vein, it has been claimed (LUTZ, 1990, p.69) that both the common sense as well as the specialized literature attributes more emotionality to women and more rationality to men. By identifying emotion as chaotic or irrational, and subsequently, labeling women as a more emotional gender, the ideological subordination of women is reinforced. Also, regarding types of emotion, women are expected to experience a wider range of emotions whereas only some types of emotion are assigned to men, particularly those of anger and hatred.

This has implications because the social value attributed to certain types of emotion might favor men, whose emotions are viewed as more important, more reasonable, and more explainable than those of women. While emotion has been generally perceived as an essentially female characteristic, for man it has been seen as something conditioned to specific situations (HOCHCHILD, 1985).

In a different vein, emotion has been viewed as a cultural discursive practice (ABULUGHOD \& LUTZ, 1990). This perception values the richness of specific situations and 
the role of language use, attempting to detach emotion from its individual and essentialist sphere. The emphasis on discourse favors a more complex view of the multiple and mutant meanings of emotion. It avoids thus essentialist concepts that tend to ignore the role of culture, language and gender in emotional exchanges and propositions.

In this paper, gender and emotion are viewed as constitutive part of discourses that form social practices shaped by power and ideologies, as suggested by some critical discourse analists (FAIRCLOUGH, 1992; VAN DIJK, 1990).

\section{Exile}

In a generic and traditional perspective, exile can be viewed as something that is mostly accomplished under the form of political ban, voluntary expatriation, or emmigration for economical or religious reasons. However, in a more specific view, it may be circunscribed to an even more personal level when, for example, the exile participants are forced to leave their native country due to very private reasons, such as the undergoing of a forbidden love affair. In that sense, Evelyn Scott and Cyril Kay-Scott may be considered not only law fugitives but also exiles, since after the breakout of the Great War they find themselves caught in the human condition of exile in Brazil.

In any case, whatever its origin or motivation may be, exile is both a profound and unique human experience. And as a research theme, it has occupied a central place within the various fields of knowledge.

In Western literature, particularly, classic works such as the Odissey, the Greek epic poem ascribed to Homer, and Oedipus Rex, by Sophocles, had already approached the topic. In these influential works, the most ancient forms of exile point out the suffering characteristic of the exile condition. However, modernity admits new meanings and concepts from the XIXth Century on, when the exiled becomes someone intrinsicly associated with the alienating condition of the modern man and world (BRADBURY \& MCFARLANE, 1991).

Adorno, as a prestigious voice of the XXth Century, pointed out that the modern alienation applies to everyone, including and especially to those in exile whose physical exile is felt twice as much. Adorno was an exiled himself in the United States, and in his view every immigrant writer feels mutilated because he or she is caught in a new environment, which is completely ininteligle to them (ADORNO, 1978)

Edward Said (2000) also states that, on the whole, any person who is prevented from returning home can be considered an exiled. For the writer, physical exile is an instigating thing to be thought about, but terrible to be actually experienced. It can in fact be compared with an unhealing wound, or a deep sadness that can never be overcome between a human being and their native land (SAID, 2000, p.91).

This paper adopts the idea of exile as anyone who, in one way or another, is caught on a situation in which the choice of returning home is not available. Evelyn Scott and Cyril Kay-Scott did choose to leave the United States for Brazil, however, after arriving in Brazil, they could not return to their native land due to war restrictions. In that sense, one can say that they may fit halfway two categories: the one of voluntary exiles and that of self-imposed exiles. The first, because they chose to leave their country, the latter because they were prevented from returning home. 


\section{Contextualizing method and material of analysis}

The method adopted in this paper follows the criteria of a qualitative analysis inspired by the notion of discourse as social practice (FAIRCLOUGH, 1992; VAN DIJK, 1990). In-depth analysis of the material is thus developed under the assumption that the material in focus is viewed as historically situated discourses. And while they convey ideologies they also shape and are shaped by the culture and society in which they are produced.

The material comprises the autobiographies Escapade (SCOTT, 1995 [1923]) and Life is too short (KAY-SCOTT, 1943), whose powerful accounts can be considered a type of discourse circunscribed to the wider field of life writing, "a generic term used to describe a range of writings about lives or parts of lives that include [...] memoir, autobiography, biography, diaries, letters" (LEADER, 2015, p.1).

Both biographies have been compared so as to identify differences and similarities regarding the way the Scotts perceived and experienced the new country. This kind of comparative methodology allows identification of ideological aspects of gender that might separate or approach the Scott's perception about Brazil and their Brazilian experience.

According to Evelyn Scott, she wrote her autobiography in loco. In Escapade, she affirms that she took daily field notes in Brazil, from 1913 to 1919 - notes that served as the foundation for the final writing process of her autobiographical masterpiece first published in the United States in 1923. Cyril Kay-Scott also took notes during their exile. However, his Life is too short was not published until much later, in 1943, twenty years after the publication of Escapade.

The Scott's autobiographical accounts reveal how they perceived the radical adventure shared in Brazil. They also reveal that they observed very closely important ritualistic social moments of the Brazilian culture, such as birth, death, and festa, topics that became dear to them, especially to Evelyn Scott. The material is thus unique, providing various possibilities for research. However, in this paper the excerpts selected are mostly concerned with issues of gender and emotion expressed in their discourse. The reason for this choice relies on the importance of analysing voices of different genders, generations and power relations reporting the same social experience.

\section{A gendered emotional exile}

In their optimistic minds and passionate hearts, the tropical paradise represented a place where Cyril Kay-Scott would find a job as a researcher of tropical especimens and Evelyn would have the time and peace of mind to free her imagination and become the writer she had longed for since she was a child. However, when the couple arrived in Brazil, problems of survival and integration started to emerge as soon as they disembarked in Rio de Janeiro. Related to gender, some of these problems affected Cyril, who, as the male provider, could not secure the idealized job of researcher of tropical specimens. Other problems affected Evelyn in particular as she had two fundamental survival concerns associated with health and sense of belonging. One was the sheer reality that she had become pregnant and was constantly suffering from morning sickness. The other was her complete helplessness to comunicate in the new environment as she could not understand or articulate a single word of Portuguese. 
Already in the first paragraph of Escapade she describes how she felt when, in their modest room of Hotel Rio Branco, she heard:

[...] a knock at the door, and the Portuguese girl entered, very slovenly, her coarse black hair hanging in stiff locks against her full florid cheeks. When she said, "Bom dia", I understood that, but the rest of her speech was a harsh murmur of gultural sound and depressed me with its strangeness. (SCOTT, 1995, p. 1)

Evelyn had immediately realized how crucial the mastery of the new language would be for her difficult process of adaptation to the new reality:

John's gaze, always so still and kind, opened on me first. Then he talked to the girl. In the interchange of unintelligible noises, I felt my exclusion from the life about me, my helplessness. (SCOTT, 1995, p.1)

Over the time, what seemed to be initial difficulties became actually serious permanent problems for both of them. The drama became obvious that they tried to return to the United States soon after arriving in Brazil. However, far too involved with their own feelings and problems, they did not have fully realized the devastating consequences of the forthcoming declaration of World War One, which would force them to remain in the country for further five long years.

I think of the three thousand miles between here and New York [...] At any rate that isn't before us. It is perfectly definite now that our passaport application has been refused. [...] We will live here somehow untill the war is over and then perhaps we can get back to the coast and, without a passport, return to the States. I will be glad to leave here. (SCOTT, 1995, p. 175)

Their desire to leave Brazil was genuine but, without any prospects of returning home, they began to consider acquiring Brazilian citizenship instead. Nevertheless, the very same war situation proved the intangibility of the plan:

We have tried to become naturalized Brazilians - even paid a little to the lawyer we had to consult - but people of warring nations will not be accepted as citizens by the Brazilian government. (SCOTT, 1995, p.147)

Prevented from returning to their homeland, Evelyn and Cyril felt exiled in two dimensions. One related to their host country, Brazil, and its war constraints that would not let them go, and another related to their own country, whose society, with its severe judicial constraints, had forced them to leave. For Evelyn Scott in particular the devastating effects of this situation turned Brazil, their host country, into a kind of prison. In midst of such ordeal, Evelyn faces a crisis of belonging in which she felt as though she had no place either under the shade of banana trees in the backlands of Brazil or close to the sensuality of the palm trees on the American coast:

I know my country is not here around me where the pale light through the banana leaves is thin and poignant, nor there, where the palm trees sway like young girls dreaming after last night's dance. (SCOTT, 1995, p.75) 
In any case gender plays a decisive part in the couple's odyssey already in the early stage of their story when we notice that the choice for Brazil had two reasons which met Cyril's conveniences only. The first reason is related to his sense of adventure and vocation to explore the untouched. He was fascinated by the greatness of the Amazon rainforest, where he hoped to work as a researher of tropical specimens. The second reason is related to a more fundamental element of survival in a new country: the mastery of its language. Cyrill spoke Portuguese, Evelyn didn't.

As a man and provider, who mastered the new language, Cyril Kay-Scott could occupy many layers of public sphere and even enjoy his travels around the country both for business purposes and for provision. He was thus more exposed to a process of genuine social interaction (SCURA, 1995) and could probably find more energy to fight his own suffering. Evelyn, in contrast, was almost all the time isolated, confined to a precarious domestic space. Without the possibility of proper social interaction, she felt "drowned in ennui", oppressed by gender issues within a new reality in which she resented the fact that "the women greeted me with hostile eyes, and the men pursued me with their shallow cloying looks" (SCOTT, 1995, p.30). One cannot forget that her autobiographical masterpiece is surprisingly dedicated to tropical animals not to human beings, as we are going to see later here.

Considering Evelyn Scott's painful isolation in Brazil, it is not surprising that Cyril Kay Scott (her only companion) be a constitutive part of her autobiographical discourse. However, the same does not apply to him who, as mentioned, was not exactly isolated.

What I would like to claim is that they experienced a gendered emotional exile because, although both of them were affected by the hardships of integration, they experienced and responded to these difficulties differently. So much so that Evelyn, at a certain point, would claim that "Men have their own engrossments and unless you exhibit your emotions they are apt to ignore troubles under which the helpless other-sex is being crushed" (SCOTT, 1995, p.214), while Cyril Kay-Scott would - today we can say - candidly claim that "In isolation, women who can't make a bed, a pie, or a garden, make a situation”. (KAY-SCOTT, 1943, p.123)

Evelyn is here complaining about a supposedly male mental framework in which, immersed in their own universe, men would have difficulty to face the basic aspects of a couple relationship. Cyril, on the other hand, resources to irony to criticize a supposedly typical bourgeois female incapacity to deal with the hardships of life, particularly the household management within precarious contexts such as the one they were enduring in the backlands of Brazil.

Their differences in worldview are visible even in the titles of their books - Evelyn's, Escapade, Cyril's, Life is too short. The first one evoking the truth of a particular event, that is, a desastrous elopment of lovers who, on the spur of the moment, fled from the United States without passports, carrying only a few pieces of closing in the uneasy historical pre-World War One context. The latter, suggestting a general statement about life regarded as ephemeral thus worthy of living it fully with all that it takes.

Regarding differences in style and worldviews, another point worth noticing is the dedications of the books. Reflecting his connection with social conventions, and the representation of family as a successful project, Cyril records in imposing capital letters "TO MY FAMILY OF ELEVEN CHILDREN AND GRANDCHILDREN THIS BOOK IS DEDICATED”. (KAY-SCOTT, 1943)

Evelyn, in contrast, deconstructs conventional patterns of dedications to pay homage to her beloved exotic tropical animals (her true companions in Brazil) rather than to fam- 
ily or friends. She thus boldly writes down, not in imposing crying like capital letters but in elegant subtle italic:

To Adám, the monkey; Dinah, the tan and white bitch; the armadillo, a small unrelenting secret; the owl; the hawk; the deer; the mangy [mendgi] little chicken who lived in a cotton nest after its leg was hurt. To the delicious goats, and all the little birds with sunken breasts and rigid claws - my friends who are dead, who loved me for no more than the food I gave them. (SCOTT, 1995)

Contrary to Cyril Kay-Scott's dedication, that explicitly displays a kind of reconciliation with his social and family network after the Brazilian adventure, Evelyn Scott's suggests displacement from the family establishment and, at the same time, reveals her freedom of thought and artistic expression.

Another illustration of how gender affects their perceptions of the exile experience can be seen in their reports about their short stay in the outskurts of Rio. Although Evelyn felt constrained by the difficulties with the new language and environment, she seemed willing to integrate and help her partner. She uses the inclusive first-person plural pronoun to describe the activity of collecting insects for scientific purposes.

[...] we went out every morning with our nets: two green gauze ones for butterflies, and two canvas sweeping bags for beetles and the like. [...] I wore an old khaki riding skirt divided in the middle, and John was in overalls with a beach hat too small for him perched high on his head. (SCOTT, 1995, p. 19-20)

Evelyn's active participation can also be seen when Cyril worked as accountant in one of the Singer sawing machines firms. On a certain occasion, he had problems regarding calculations in the booking of the firm and, again, Evelyn was by his side trying to help " [...] Not long ago there was a mistake in his accounts and he was unable to discover it. He brought home the long sheets of paper and we worked together over them" (SCOTT, 1995, p.7)

Regarding these two specific situations, it is interesting to notice Cyril's difference in approaching the memory of events. About the collecting of specimens in Rio, unlike Evelyn, who uses the first-person plural pronoun, Cyril uses the non-inclusive first-person singular pronoun to describe the same event:

Arriving in Rio de Janeiro, [...] I started at once my collecting trips around the Federal District. [...] I collected hard, going out every day all day. (KAY-SCOTT, 1943, p.176-177)

Similarly, with regards to the accounts of problems in the firm where he worked, Cyril, once more, resources to first-person singular pronoun to describe the situation:

[...] So, a few at a time, I took jornal, ledger, store invoices, receipts of sales, records of installments payments, reports, and other things home at night and worked late over them. How I sweated over those books! (KAY-SCOTT, 1943, p.179)

These are just some initial (perhaps still too generic) observations that might help contextualize autobiographical narratives that unveil important differences both in style and worldviews between Evelyn Scott and Cyril Kay-Scott. 


\section{The increasing process of isolation}

In order to better understand the couple's process of isolation, it is important to highlight that due to the lack of knowledge of the language as well as to gender roles of the time, Evelyn became more and more dependent on Cyril, therefore, more and more exposed to a process of extreme isolation. This mental process unveiled a profound sense of boredom in which the writer resented her systematic lack of occupation.

[...] I want to feel, to feel anything - to purge myself of the heavy turgidness of the thoughts that come to me as I sit alone day after day with no definite occupation. (SCOTT, 1995, p.13)

Cyril, as man and provider, did not stop. He was always busy and to a certain extent happy with his Singer's employee life, which allowed him to travel, better explore the country, and learn new things. While for Cyril the hard life of exile proved to be also a motivating experience, for Evelyn it was a torment dominated by isolation and nothing to be occupied with. It was almost impossible for Evelyn Scott to establish genuine contact with the new reality and when her companion was not home, she simply "set there in the room with nothing at all to occupy me - nothing but my thoughts". (SCOTT, 1995, p.2) Her exasperating degree of isolation can be infered through the use of metaphors expressing the idea of lack of occupation as drowning, becoming blind, and being imprisoned. Images that express impossibility of survival of the body itself.

I felt as if I was drowning in ennui. As if the sun had blinded me. Yes I was a blind person. In the long days when John was away I should have to sit there in my white empty prison, a prison in which nothing moved but the irradiation of the glare, in which there was no aim, no interest. (SCOTT, 1995, p.30)

Despite the desire to write, Evelyn Scott felt paralized by those conditions and tried to explain the drama to herself.

If my brain was dead my hands and arms were dead also. [...] I imagined myself bound in the heat forever. [...] The heat was cold. It burned like ice. I wanted to be a writer but I had nothing to write about. (SCOTT, 1995, p.30)

For Evelyn Scott the intelectual paralysis seemed unbearable, "Ennui is the most awful thing I have ever had to bear. I sit here hour after hour and my brain is clasped with iron" (SCOTT, 1995, p.38). It is a difficult emotional state for the writer for whom "When I wake in the down there is quiet at last, and I lie there in the cool shadow of lonelyness." (SCOTT, 1995, p.40)

In the midst of such creativity and integration crisis, one of her self-defense strategies against the complete lack of occupation was to develop true obssession for household tasks, "I did nothing but cook, and clean and splash buckets of water upon the brick floors. I had no interest in anything else" (SCOTT, 1995, p.49-50).

Evelyn Scott, as a pregnant woman in state of domestic hiper activity and as a writer going through a crisis of thinking, abandonned herself to the incapacity of putting in practice her desire to write, "I took a pencil and some paper from my handbag. If I could 
only write! But I had no thoughts. What possessed me completely was the faint disturbing nausea of my pregnancy" (SCOTT, 1995, p.49-50).

\section{Extreme isolation: Cercadinho}

Finally, when everything seemed dramatically impossible for the couple's survival, Cyril decided to quit everything and buy a piece of land in the backlands of Bahia with the intention of becoming a rancher to live beside Evelyn and their son in Cercadinho, a place near the small town of Villa Nova da Rainha, today, a medium size city known as Senhor do Bonfim. Living within a context of complete dependency, Evelyn accepted the situation and seemed not to have taken any part on the decision.

It took John three days to return to us [...] he wants to resign the Company, draw out our garantee fund, buy some government land he has seen and stock it with sheep. [...] He will begin by asking a leave of absence on account of my health and in that way he can keep his salary untill we have moved and are actually in the vicinity of the ranch. (SCOTT, 1995, p.159)

For Cyril, the decision had been taken in order to stay closer to his family. But in addition to that he seemed excited about the new adventure. "We were pioneers" (KAYSCOTT, 1943, p.218), he says, referring to the family's triumphal departure that, under his leadership, had traveled with

[...] seven pack mules and ten men, six of the men with extra mules for riding, or in case of accident to pack animals, and four Indians on foot who carried two trunks strung on poles, exactly as the Bihéans in Africa carry a tepoia.(KAY-SCOTT, 1943, p.218)

As they arrived in Cercadinho, Cyril still seemed quite excited with the novelty, showing himself particularly touched with the beauty of the region. "Our arrival at Cercadinho was a great event. The beauty of the place was breathtaking. No one could resist it. Even Mrs. Dunn agreed that it was a nice landscape" (KAY-SCOTT, 1943, p.218). And he was also proud of his achievements as house builder "The big palm-covered hut was there, and my women folk were agreeably surprised at its great size". (KAY-SCOTT, 1943, p.219)

In general, his descriptions about their moving into the backlands are as positive as possible, expressing emotions that encompass sensation of pioneerism and feeling of astonishment with the beauty of the surroundings. But Evelyn was undergoing a different emotional process. It was in Cercadinho that she experienced utmost isolation and had her interactional life reduced to the minimum, that is to say the contact with her unbalanced mother, who had left the United States to join hem in Brazil, a maid, and her baby son.

While John was in the mountains measuring our land, Nanete, Estephania, Jackie, and myself, lived in a small dirty house [...] only two of the rooms had windows, but the doors at the back opened into a small overgrown garden with a high mold-green wall around. I felt lonely, separated from everything, like a sward pointing up, as if, in the pain of isolation, I were piercing heaven, piercing the world. (SCOTT, 1995, p.167) 
Although Cyril had resigned from Singer in order to stay closer to Evelyn, in Cercadinho he still would have to be away from home either to search for provisions in nearby villages, or to work the soil in order to make Cercadinho a more habitable place. So, Evelyn's isolation grew bigger and bigger and she also began to miss a more intimate contact with her husband.

For some reason I imagined John had gone away from me forever, that he would never come back. I could, for the first time, see him whole, like an immortal, unbroken by words. Unable to send a message to me, he was gone for three weeks. His silence seemed to me beautiful, finished, but I wanted him again. I wanted to destroy his perfection with intimacy. (SCOTT, 1995, p.167)

After approximately three years of isolation in the backlands of Bahia, the dream of turning Cercadinho into a productive piece of land was destroyed by drought and a series of diseases that killed plants and animals, forcing the couple to face bankrupticy, starvation, and despair.

Our ranch is an utter failure. [...] The sheep [...] die and die [...] Sometimes for weeks at a time we have no meat. The last we bought when we disposed of the sick mare and the hides of two of the sheep that were in a better condition than the rest. We eat a little piece and hang the remainder from the rafters, and every day, for as long as it lasts, we have a bit. I used to throw away the portions on which the flies had laid, but now I scrape the eggs and maggots away as best as I can and we have that, too." (SCOTT, 1995, p.229-30)

That extreme hardship of the situation made Evelyn feel as though they were "going mad, and [...] as drunk with suffering as any of the mule drivers are drunk with rum" (SCOTT, 1995, p.236). However, the wider historical context seemed to favor them according to Evelyn.

John heard same marvelous news. Because of the war "down there" a new mining company - an American company has begun to operate along the coast and is sending men into the interior to locate manganese workings - manganese for the making of steel armament. (SCOTT, 1995, p.249)

In hearing the news Cyril begin to think about the American mining company as a escape for his family's desperate situation. But in the meantime, Evelyn tried to cheer herself up by doing something useful in favor of the humble locals who surrounded her.

As for myself, I am eternally in quest of an occupation which will distract me, and I am teaching Antonio and Jovina how to sign their names and to read. (SCOTT, 1995, p.248)

\section{Leaving Cercadinho}

Bypassers were rare in Cercadinho but the few who passed confirmed the news of the recruitment of employees by the American mining company. Thus, when everything seemed absolutely hopeless for Evelyn Scott and Cyril Kay-Scott, they saw the possibility of moving out with their family to the small town of Vila Nova da Rainha, today, 
Senhor do Bonfim, where he could work. Ironically, the same War that had forced them into isolation and exile would be now their only chance of making their way back to the United States.

The couple's reports about Cyril's decision to give up the dream of Cercadinho in exchange for an oportunity at the mining company converge. According to Cyril,

As soon as I verified the rumor I made a decision. In persuance of it I walked the eleven kilometers over to my Negro neighbour Hylarião's cabin. [...] And it was his clothes I wanted to borrow. [...] The suit (sky blue, as I have said, and gored in at the waist) fitted me terribly. [...] Also I was barefoot, but that didn't matter, as I had gone barefooted for over a year and my feet were like sole leather. [...] At daybreak I said good-bye to my family and started through the canyon. (KAY-SCOTT, 1943, p.245)

Evelyn seemed to agree about almost everything that was pointed out by Cyril and highlights that

John has determined to secure a position with the mining company. He borrowed some clothes from Tenente Alfredo Hylarião in Lamarão and has gone on foot to Vila Nova. When he left here he was barefoot for he had to save the shoes. The blue suit he wore, the work of a provincial tailor, was very tight in the trousers, very small in the waist - almost ridiculous. (SCOTT, 1995, p.252)

A curious detail, though, calls the attention regarding the care given to Cyril's appearance in order for him to make a good impression during the important transition journey. While Evelyn says that she herself had "trimmed his beard and cut his hair, but he had no raizor so he must wait to reach his destination before he can shave" (SCOTT, 1995, p.252), Cyril gives all the glory of the care to their maid Stephania:

That evening Stephania cut off my long hair and I shaved my beard. The next morning, she rose before dawn and got me coffee and breakfast. The shoes [...] she tied in her best gaily printed big cotton handkerchief she kept to wear on Sundays. (KAY-SCOTT, 1943, p.245)

Futhermore he makes a point in saying that "she, by the way, is the heroine of this part of my tale". (KAY-SCOTT, 1943, p.213)

\section{Final remarks}

This article investigated issues of gender and emotion within the context of exile, drawing from Evelyn Scott's autobiography Escapade and Cyril Kay-Scott's Life is too short. The couple took refuge in Brazil after having eloped from the United States in 1913. With the outbreak of World War One, however, they found themselves trapped in Brazil with no chance of leaving the country due to its law restrictions. As a result, they moved from place to place until they eventually made their way to the backlands of Bahia, where they faced extreme poverty, isolation, and despair.

The investigation has shown that gender and emotion play a crucial role in the Scotts' exile experience as well as in their autobiographical accounts of the experience. 
In conclusion, I would like to emphasise that Evelyn Scott and Cyril Kay-Scott's autobiographical narratives show that both of them went through great material as well as existencial difficulties in Brazil and lived a very complex range of emotional experiences shaped by gender within their self-imposed exile. However, within that complex emotional framework, isolation strikes Evelyn in a particularly destructive way. As a result, the writer constructs a dark autobiographical discourse about her Brazilian exile, especially with regards to the hardship found in the backlands. Although she uses beautiful poetical forms to describe local landscape, the images evoked by her poetical language are usually disturbing, indicative that virtually everything in their Brazilian exile seemed ugly, painful and difficult to her. Differently, for Cyril Kay-Scott, the experience, although also painful and difficult, had a flavour of adventure and pioneerism in which the writer seemed enthusiastic with the possibility of exploring the new landscape and challenging the dangers of nature, from the power of the Amazon river to the inhospitable climate of the backlands.

Evelyn Scott is today a well-known writer in the United States. She wrote in many genres, from poetry to prose. But it is in the confessional genre of autobiographies that the critics have recognized the highest literary quality of her work. In Brazil, however, there is almost no record of her work except for the contributions of Otto Maria Carpeaux (1947) and Beatriz Jaguaribe (2000), whom, from diffrent perspectives and in different historical contexts, brought to light Evelyn Scott's work in the country.

Carpeaux, an Austrian-born writer who had left his country before the deflagration of World War Two to adopt Brazil as his home, soon acknowledged Evelyn Scott's genious. In a newspaper article published as far back as 1947 he highlighted the originality of Evelyn Scott's modern autobiographical style and warned Brazilian translators that Escapade was a true masterpiece.

As for Cyril Kay-Scott, besides being a doctor of tropical medicine, scientist, and educator, he also had an artistic vein and composed some plays, and wrote short stories, and poems. However, he did not become the established writer that Evelyn Scott did, and in Brazil, where there is no record of any systematic academic research about his work, he remains practicly unknown.

While it is hoped that this article may contribute to disseminate Evelyn Scott's life and work, it is also important to point out the need for further research on the role of gender and emotion in exile experiences involving couples in isolation.

\section{References}

ABU-LUGHOD, Lila; LUTZ, Catherine. Introcuction. In: Language and the politics of emotion. Cambridge: Cambridge University Press, 1990.

ADORNO, Theodor. Minima Moralia. Trans. E.F.N. Jephcott. London: Verso, 1978. BUTLER, Judith. Gender troubles: feminism and the subversion of identity. London: Routledge, 1990.

BACH, Peggy. Evelyn Scott: 1920-1988. Bulletin of Bibliography 46.2 (1989).

BRADBURY, Malcom; MCFARLANE, James. (eds). Modernism: A Guide to European Literature 1890-1930. London: Penguin, 1991.

CALLARD, David. Pretty Good for a Woman: The Enigmas of Evelyn Scott. New York: Norton, 1985. 
CAMERON, Debora. Feminism \& Linguistic Theory. London, Macmillan, 1985.

CARPEAUX, Otto M. "Reflexos do Brasil”. A Manhã, Rio de Janeiro: Suplemento Letras e Artes, 1947.

ECKERT, Penelope; McCONNEL-GINET, Sally. Language and Gender. Cambridge: Cambridge University Press, 2003.

FAIRCLOUGH, N. Language and Power. London, Longman, 1989.

"Introduction" In: Critical Language Awareness, London, Longman, 1992.

FOUCAULT, M. The order of discourse: an archeology of the Human Science. London, Tavistock, 1972.

FOWLER, R. Language in the News: Discourse and Ideology in the Press. London, Routledge, 1991.

GOFFMAN, E. Gender Advertisements. New York, Harper \& Row, 1979.

HOCHCHILD, Arlie. The managed heart. Berkley: University of California Press, 1985.

JAGUARIBE, B. Fuga tropical: Evelyn Scott e Cyril Kay-Scott no Brasil. In: Cristina Stevens (org). Quando o tio Sam tocar o tamborim: uma perspectiva transcultural do Brasil. Brasília: Editora Plano, 2000.

JONES, Paul C.; SCURA, Dorothy. Evelyn Scott: Recovering a Lost Modernist, Knoxville: University of Tennessee Press, 2001.

KAY-SCOTT, Cyril. Life is too short. Philadelphia, New York: J.B. Lippincott Company, 1943.

KESSLER, Susane; McKERMMA, Wendy. Gender: an ethnometodological approach. Chicago: University of Chicago Press, 1978.

LAKOFF, R. Language and Woman's Place. New York: San Francisco, London, Harper \& Row, 1975.

LEADER, Zachary. On life-writing. Oxford: Oxford University Press, 2015.

MAUN, Caroline. Mosaic of fire: the work of Lola Ridge, Evelyn Scott, Charlotte Wilder and Kay Boyle. South Caroline: University of South Caroline Press, 2012.

SAID, Edward. Reflections on Exile and Other Essays. Cambridge: Harvard U P, 2000. SCOTT, Evelyn. Escapade. Afterward by Dorothy M. Scura. Charlottesville and London: University Press of Virginia, 1995 [1923].

SCURA, Dorothy. Afterword. In: Evelyn Scott, Escapade, Charlottesville and London: University Press of Virginia, 1995 [1923].

WELKER, Robert L. Evelyn Scott: a literary biography. Diss. Vanderbilt U, 1958.

WHITE, Mary. Fighting the current: the life and work of Evelyn Scott, Louisiana: Louisiana State University Press, 1998.

VAN DIJK, Teun. Social cognition and discourse. In: GILES, Howard. \& ROBINSON, William P. Handbook of Language and Social Psycology. Chichester: Academic Press, 1990. 